\title{
EVALUATION OF INTELLECTUAL CAPITAL IN PRODUCTION
}

\author{
Elena Shirinkina \\ PhD of Economic science \\ Government budget educational institution of higher education "Surgut State University of \\ Khanty-Mansiysk Autonomous Okrug - Ugra" \\ 1 Lenin str., Tyumen region, the Khanty-Mansiysk Autonomous Okrug, \\ Surgut, Russian Federation, 626400 \\ shirinkina86@yandex.ru \\ Maxim Shpak \\ Government budget educational institution of higher education "Surgut State University of \\ Khanty-Mansiysk Autonomous Okrug - Ugra” \\ 1 Lenin str., Tyumen region, the Khanty-Mansi Autonomous Okrug, \\ Surgut, Russian Federation, 626400
}

\begin{abstract}
In the article was elucidated the essence of intellectual capital and its role in productive activity. At establishing the knowledge-based model of economy the formation of intellectual industrial property as one of the main components of intellectual capital of existing productions needs planning, clear organization and motivation of this process. The author defined an attempt to evaluate an effectiveness of using intellectual capital as the problem of research. The categorical essence of intellectual capital was analyzed from the positions of the different authors. There was offered the author's classification of intellectual capital content where it is divided into internal and external structure and also in the staff competence. At the same time there is the certain correspondence between the structural components of intellectual capital in both variants of their singling out. There was offered the system of interconnection between the objects of intellectual capital and technological processes or means of technological equipping applied to the subdivisions of the main and auxiliary productions. It was grounded, that the management of intellectual capital needs planning, clear organization and motivation of this process through the analysis of costs connected with its creation. There was offered the quantitative assessment of the effectiveness of intellectual capital use. There was established the value of this parameter as the reference point for attainment of the effective innovative development of industrial enterprises.

Keywords: intellectual capital, classification, structure, evaluation, parameters, effectiveness, production, technological process.

\section{Introduction}

The growth of interest of economic science to the problems of intellectual capital is conditioned by the fact that its effective management is for today the main way of guaranteeing the scientific-technological progress, competitiveness and stable economic growth of productive organizations and the national economy as a whole. The stable economic growth of productive organizations is possible on the base of intensification of innovative activity connected with the process of intellectual capital formation. The modern theory and practice of organization of management of production consider the degree of its intellectualization as a characteristic that reflects the effectiveness of its functioning in the competitive environment that is intellectual aspects of the productive enterprises development are moved to the forefront. Within the world economic system which main attribute is information and knowledge the tendency to formation of intellectual production cause the necessity of the further elaboration of theoretical and practical aspects of intellectual capital, its evaluation as a factor of production. These circumstances indicate the special topicality of the considered problem.
\end{abstract}

\section{Analysis of the literature data and statement of the problem}

The influence of intellectual component on the economic development, competitiveness and stability of the economic systems functioning is studied in the different native and foreign schools. 
The study of interconnection between the intellectual capital and economic growth of productive organizations was realized in such works as «Patent Statistics as Economic Indicators» [1], where is mentioned the intangible capital in patent statistics. In the work "New industrial society" [2] the notion "intellectual capital" was firstly introduced. In the work «Intellectual Capital» [3] the notion "intellectual capital" was properly grounded and rather widely popularized. In the monograph «Mobilizing Invisible Assets» [4] was firstly considered the structure of intellectual capital. But the questions of theory and practice of the management of the process of involving the intellectual capital objects in the economic circulation, elaborating the methodological grounds of the management results of creative activity still insufficiently studied.

\section{Aim and tasks of research}

The aim of research is elaboration and grounding of theoretical and methodological approaches to the management and evaluation of the intellectual capital of enterprises as a factor of economic growth and the policy directed on involving the results of intellectual capital in economic circulation for attaining the high competitiveness and functioning quality.

According to the set aim were defined the following main tasks:

1. To offer the author's classification of the intellectual capital content.

2. To ground the system of interconnection between the intellectual capital objects and technological processes or means of technological equipping applied to the subdivisions of the main and auxiliary productions.

3. To ground the needs of intellectual capital management.

4. To offer the quantitative evaluation of effectiveness of the intellectual capital use.

\section{The study of intellectual capital essence}

The notion "intellectual capital" was introduced into scientific circulation by J. Galbraith [2] in 1969. As it was indicated above, it is wider than the habitual notion "intellectual property". At the same time by the meaning it is close to the notions "intangible, immaterial, nonphysical capital" used in the works on econometrics at least since 1990. In Griliches' classical work on the use of the patent statistics in economic dimensions [1] the intangible capital is considered as the natural unobserved parameter raising the market value of the firm and depending on the number of its patents, volume of investments in R\&D and other analogous factors.

T. Stuart was the first one who properly grounded and rather widely popularized the notion "intellectual capital". It was he who defined intellectual capital as a sum of all that know the workers of company and what gives the competitive advantage to the company on the market [3]. Further the definition of intellectual capital was specified. Thus L. Edvinsson from the Scandia defined intellectual capital as the knowledge can be converted in the cost [5], and according to L. Prusak from IBM - it is an intellectual material that is formalized, processed and used for increasing the costs of the company's assets. In the further specifications of the notion of intellectual capital the special attention was paid to its static characteristics connected with the process of accumulation of intellectual assets such as patents, licenses, computer programs, copyrights and so on and the dynamic ones connected with the human resource of organization and innovative activity.

The essential additions to the definition of the intellectual capital nature were made by the Japanese scientists, especially, I. Nonaka. In his interpretation the accents are moved to the creation of the new knowledge, innovative process with the use of so-called tacit that is implicit knowledge [6]. According to P. Druker [7] this the knowledge of the knowledge worker who differs from the other participants of the working process by the complete possession of his own "productive means": intellect, memory, initiative, personal experience that belong to him. One of the first native researchers who considered the problem of intellectual capital was V. S. Efremov. According to his definition [8], intellectual capital it is the knowledge of organization but expressed in the clear unambiguous and easily transferred form, for example, in the form of the program support. So, from the given analysis flows that the notion "intellectual capital" that can be used by the managers at the organization of staff and immaterial assets, at creation of the favorable image of the firm for attracting investments and at the assessment of business based on knowledge for its purchase or sale. 
To find the connection between the intellectual and human capital, let's consider their internal construction. For today there is no common notion of the structure of aforesaid objects. Thus in fundamental work of T. Stuart, one of the founders of the modern theory of intellectual capital, [3] are separated its three components: human, organizational and also consumer or client capital.

The human capital is understood as the part of intellectual capital that has the direct connection with human (knowledge, practical skills, creative and thinking abilities of humans, their moral values, labor culture) [9-11]. The human capital is important at innovations and any renewal. The term "human capital" was introduced in scientific circulation near 1962 by F. Mahlup, moreover it was further used in connection with economy of knowledge exactly. In the history of development of this component of intellectual capital the start of its use corresponds with the publication of the H. Itamy's monograph in Japanese [4] then with the P. Sullivan's work [12].

Organizational capital includes the component of intellectual capital connected with organization as a whole (procedures, technologies, systems of management, technical and program support, patents, trademarks, organizational culture and so on). As we can see, the structure of organizational capital includes the elements of intellectual property. Organizational capital is in essence the organizational possibilities of the firm to react on the market demands. It guarantees the use of the human capital in organizational systems, transforming information. Organizational capital is mainly the property of the company and may be the relatively independent object of purchase-sale.

The notion "client capital" was introduced by ST. Gerbert in 1993. Consumer or client capital is formed by connections and stable relations with clients and consumers. The one of the aims of forming consumer capital, according to T. Stuart, is the creation of structure that allows the productive communication between the consumer and company staff.

We offer the other classification of intellectual capital content where it is divided into internal and external structure and also staff competence. At the same time there is the certain correspondence between the structural components of intellectual capital in both variants of their singling out. Organizational component corresponds to the internal structure, consumer one - to the external and the human one - to the staff competence. Staff competence is offered to include: an ability to act in the different situations, education, qualification, skills and abilities, experience energy, attitude to the work, clients, level of general culture that is the human capital, according to T. Stuart. The internal structure includes such elements as projects, computer and administrative systems, systems of net interaction, organizational structure, organizational culture and also the objects of intellectual property: knowhow, patents, copyrights and other that is closed by content to the T. Stuart's organizational capital. As to the external structure, its elements are considered as the relations between the consumers, suppliers, competitors, local communities. At the same time in this structure are included the elements related to the intellectual property: brands, trademarks, image of organization. All this, according to T. Stuart, is included in the group of consumer (client) capital. As we can see, the external structure can improve the prestige, favors the finding of the new consumers. The internal one with the help of knowledge transfer allows diminish the dependence of organization on the human factor. The workers' competence can favor the elaboration of new ideas and new projects, guaranteeing in such a way the specific converting of the human capital (in T. Stuart's terminology) into the organizational one. Finally, an interaction of all structural components is transformed into financial capital.

Human capital is separated as the special position. In the other part is separated the component that is called the market (relation, client or brand) capital and also component rather heterogenic by its content called the structural capital. This classification is in certain contradiction with the T. Stuart's one. According to this approach, structural capital is the most heterogenic part of intellectual capital. It includes the right of intellectual property, information resources, instructions and methods of the work, system of the firm organization and so on. The structural capital also includes the systematized knowledge that is knowhow that can be in fact separated from the natural persons (workers) and from the firm. To the market one in the given classification are attributed: the trademarks and marks of service; firm names (according to T. Stuart, this part corresponds to the organizational capital); business reputation; the own people (insiders) in the partners or clients organizations; permanent clients, repeated contacts with clients and so on (this part corresponds to the client capital). As we can see from the aforesaid, the elements of intellectual 
property are included in at least two components of intellectual capital - market and structural or organizational ones.

\section{Materials and methods}

For the real production the objects of industrial property act as the final innovative product connected with elaboration of the technological processes or means of technological equipping (equipment, technological rigging, equipment management programs) applied to subdivisions of the main and auxiliary productions. The purposeful systemic creation of the new technologies including the means of technological equipping is realized at the stage of the research and development (R\&D) or project-technological (PT) works. These stages include the wide spectrum of works, the significant part of which can result in creation of intellectual product. In general case the work cycle includes the following stages:

- generation and elaboration of idea and elaboration of conception of technology or product;

- the natural, mathematical or imitational modeling of processes, calculations for determining the parameters of processes or constructive elements;

- the choice or elaboration, laboratory studies of materials for the working bodies and technological rigging;

- the stand tests and experimental checks;

- the elaboration, agreement and approval of the technical task for projecting technology or equipment;

- the elaboration of the project, technological or technical documentation;

- the production of test samples of equipment, test-industrial run of production.

The productive probation of the test samples of the means of technological equipping or consumer expertise of production;

- the elaboration, agreement and approval of the technical conditions for the technological rigging or production.

At establishing the knowledge-based model of economy the formation of intellectual industrial property as the one of the main components of intellectual capital of existing productions needs planning, clear organization and motivation of this process through the analysis of costs for its creation. In general case the cost of intellectual capital of enterprise must include [13]:

- the cost of R\&D used for creation of the given object;

- the cost of its patent and registration;

- the sum pays for labor contracts with inventors who create the objects of intellectual property by the order of firm;

- the sum cost for support the regime of secret on the created knowhow.

So, if the object of intellectual property on the process or mean of technological equipping is patented at the first stage of generation of idea into conception, the cost of its creation is expressed:

$$
\mathrm{Cic}=\mathrm{Ci}+\mathrm{Cp},
$$

where Cic - cost for the idea capital;

$\mathrm{Ci}$ - costs for generation of ideas and elaboration of conception;

$\mathrm{Cp}-$ costs for patent of invention.

For definition of the cost for transformation of the idea capital into intellectual product created by the enterprise at the second stage of innovative process:

$$
\mathrm{Cpr}=\mathrm{Ce}+\mathrm{Cm}+\mathrm{Cr}
$$

where $\mathrm{Cm}$ - cost of creation of the model of process;

$\mathrm{Ce}-$ costs for elaboration of the program product;

$\mathrm{Cr}-$ costs for the certificate of registration.

The attention must be paid to the fact that in the case of purchase of object of intellectual property created at the stage of laboratory tests takes place the scientific-technical risk quantitative- 
ly evaluated according to [14] with the coefficient 0,4 that is $60 \%$. Such risk after the end of R\&D decreases to $30 \%$ at the correspondent coefficient 0,7 .

Because the process of transformation of the raw material, material and the half-stuff into the ready products is directly realized in the main production, it is this process where are concentrated the most means of technological equipping: machines, equipment, transport devices, technological mediums and rigging. The function of auxiliary is mainly in service and support of the technological equipping means of the main process in the working state. For technological equipment are needed the auxiliary repair subdivisions and for technological rigging, for example, engineering production - instrumental ones. If in the equipment of the main production the working body is medium (technological solutions), preparation and support of its concentration are provided by the correspondent auxiliary subdivisions. The effectiveness of the work of the main and auxiliary subdivisions essentially depends on the level of applied technologies and technical level of the used equipment. The technical level of the main and auxiliary productions can be evaluated by the parameters of mechanization and automatization levels, mean age of equipment and processes, capital-labor ratio of the staff and other parameters. But these parameters do not allow present the level of novelty of decisions that the technological system of production is based on. The notion of novelty is used at evaluation of the scientific-technical level of production that is characterized with the totality of parameters that determine the level of novelty of the scientific principle, constructional decisions, technology, used materials.

As applied to the industrial technical production the term "technical novelty" is more appropriate. Technical novelty is the result of intellectual search, intellectual labor of the creators of the means of technological equipment that is intellectual product. Technical novelty is protected only by the patent of inventions and industrial sample, certificates of registration of the useful model, certificates of registration of copyright for computer programs and data bases formed as a technical documentation skills and knowhow productive experience, certification of the authorship of rationalization proposals. The other objects of intellectual property of industrial enterprise (right for trademark, name of the place of the goods origin, brand) are the means of individualization of products or individualization of the juridical person.

Let us consider the possible distribution of the objects of intellectual capital by the means of technological equipping of subdivisions of the main and auxiliary production. For subdivisions of the main production and also for the auxiliary ones connected with preparation and support in the working state of the working mediums and other auxiliary materials is possible the combination of all variations of the objects of intellectual property that are typical for the industrial enterprise. For repair and instrumental subdivisions including the ones of repair of technological rigging the objects of intellectual property are possible most likely as the exclusive rights for data bases and computer programs designed for the management of technological exploitation of the auxiliary equipment. As to knowhow as the special skills and productive experience, rationalization proposals for technical exploitation they become the objects of intellectual property only in the case of the beneficial use for than 12 month.

The means of technological equipping of the repair and instrumental production based on the right of the same owner (patent owner) for invention, industrial sample and useful model are practically unreal.

\section{Results of research}

Connection between the objects of intellectual capital and means of technical equipping of the auxiliary productions is presented as the scheme on the Fig. 1.

The connection between the objects of intellectual capital and the means of technological equipping of productions characterizes only the qualitative side of their technical novelty. It is reasonable to realize the quantitative evaluation by the costs of the objects of intellectual property calculated in the balance of enterprise as the immaterial assets (Cic). But the absolute value of the cost of these immaterial assets does not allow make conclusions about the importance of the technical novelty. It is obvious, that the relative cost characteristic is needed. This characteristic may be the ratio of intellectual capital coast and the balance cost of the active part of the main funds of the main or auxiliary production (equipment cost $\mathrm{Ce}$ ). 
This parameter can be called coefficient of effectiveness of the intellectual capital use:

\section{$\mathrm{Ccu}=\mathrm{Cci} / \mathrm{Ce}$.}

Because in the developed countries the share of immaterial assets in the summary assets of industrial firm is near $50 \%$ [15], and according to «WOIP-SERVAL» evaluation [16] their share in assets of the native industrial enterprise must reach 15-20\% it must be suggested that the value of coefficient that must be reached is $0,3-0,4$.

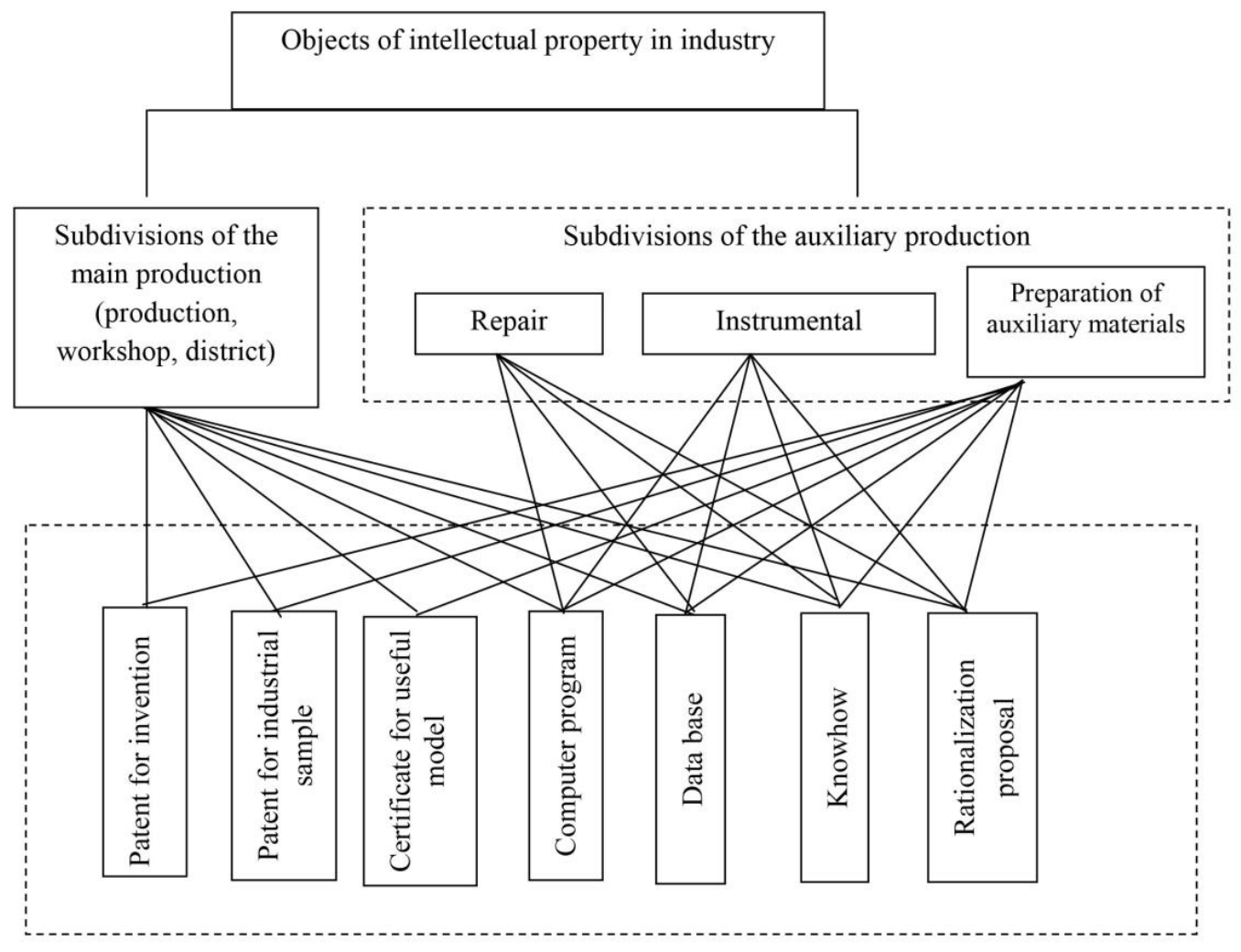

Fig. 1. Connection between objects of intellectual property with the main and auxiliary production

\section{Discussion of the results}

The advantage of this research is in the fact that such structural characteristic of intellectual capital and also its evaluation and management allow ground its use as one of the factors of forming the competitive advantages and economic growth of the productive enterprises.

Theoretical and practical importance of the results of research is in the widening of theoretical notions about the intellectual capital management and their practical appliance in innovation development of the industrial enterprises. The use of methodological approach to the evaluation of intellectual capital elaborated in the research can be the base for making decisions and improving the process of management at enterprises at introducing the modern system of strategic management, evaluating the competitiveness and cost of business.

But this research needs the further work from the aspect of elaboration of the system of parameters of evaluation of effectiveness of the intellectual capital use.

\section{Conclusions}

As the result of research were made the following conclusions:

1. The author's classification of the content of intellectual capital where it is divided into internal and external structure and also into the staff competence was offered. At the same time 
there is the certain correspondence between the structural components of intellectual capital in both variants of their singling out.

2. The system of interconnection between the objects of intellectual capital with technological processes and means of technological equipping applied to the subdivisions of the main and auxiliary production was offered.

3. It was grounded, that the management of intellectual capital needs planning, clear organization and motivation of this process through the analysis of costs for its creation.

4. The quantitative evaluation of the effectiveness of intellectual capital use was offered. The value of this parameter as the reference point of the attainment by the industrial firms was established.

\section{References}

[1] Griliches, Z. (1990). Patent Statistics as Economic Indicators: A Survey. Journal of Economic Literature, XXYIII, 1661-1707.

[2] Galbraith, J. (1969). Novoe industrial obshhestvo, 480.

[3] Stuart, T. A. (1997). Intellectual Capital: The New Wealth of Organisations. Long Range Planning, 30 (6), 953. doi: 10.1016/s0024-6301(97)80956-9

[4] Itami, H. (1980). Mobilizing Invisible Assets, 186.

[5] Edvinsson, L., Malone, M. S. (1997). Intellectual Capital: Realizing Your Company’s True Value by Finding Its Hidden Brainpower. New York: Happer Business, 240.

[6] Bespalov, P. V., Gaponenko, A. JI. et. al. (2003). Intellektual'nyj kapital - strategicheskij potencial organizacii. Moscow: Social'nye otnoshenija, 184.

[7] Druker, P. (2009). Postkapitalisticheskoe obshhestvo. Novaja postindustrial'naja volna na Zapade, 71, 95-98.

[8] Efremov, B. C. (1999). Biznes-sistemy postindustrial'nogo obshhestva: O trude, kapitale i pribyli kommercheskogo predpriiatiia. Menedzhment v Rossii i za rubezhom, 8.

[9] Kaufman, N. Ju., Shirinkina, E. V. (2016). Razvitie biznes-obrazovanija kak determinanta innovacionnogo obnovlenija ekonomiki. Fundamental'nye issledovanija, 3 (2), 385-389.

[10] Shirinkina, E. V., Kaufman, N. Ju. (2015). Ocenka okupaemosti investicij v chelovecheskij kapital. Dostojnyj trud v ekonomike XXI veka: materialy mezhdunarodnoj nauchno-prakticheskoi konferencii, Saratov: Izdatel'stvo «KUBiK», 197-201.

[11] Kaufman, N. Ju., Shirinkina, E. V. (2016). Neobhodimost' razrabotki strategii razvitija vuzov v uslovijah innovacionnoj jekonomiki. Elektronnoe nauchno-prakticheskoe periodicheskoe izdanie «Ekonomika i socium», 2 (21). Available at: http://www.iupr.ru/domains_data/files/zurnal_21/Kaufman\%20N.Yu._.pdf

[12] Sullivan, P. H. (2000). Value-driven Intellectual Capital: How to convert Intangible Corporate Assets into Market Value, 276.

[13] Kashin, I. L., Travin, M. M. (2003). Intellektual'naja sobstvennost' v promyshlennosti i analiz etapov ee formirovanija. Problemy novoj politicheskoj ekonomii, 3, 130-133.

[14] Valdajcev, S. V. (2007). Ocenka biznesa i innovacii. Moscow: Filin, 336.

[15] Problemy konkurentosposobnosti elektrotehnicheskoj produkcii. (2014). Moscow: Press-servis, 24.

[16] Shilova, E. V. (2013). Ocenka intellektual'noi sobstvennosti. Irkutsk: Izdatelstvo BGUJeP, 122. 